Mental Health Research Institute and Laboratory of Neuropathology University of Michigan Ann Arbor, Michigan

\title{
The Relation of the Formation of Lipofuscin to the Distribution of Oxidative Enzymes in the Human Brain* **
}

\author{
By \\ REINHARD L. FRIEDE
}

With 7 Figures in the Text

(Received March 30, 1962)

The extent of deposition of lipofuscin (lipochrome, yellow pigment, wear and tear pigment, ceroid) in nerve cells varies considerably among the nuclei of the brain. OBERSTEINER ${ }^{26}$ distinguished "lipophil" cells (e.g.: large cortical pyramidal cells, spinal motor cells, mesencephalic trigeminal nucleus) and "lipophob" cells such as the Purkinje cells and the cells of the Westphal-Edinger nucleus. A few more examples were added by later investigators ${ }^{19,34}$, but only SuLKIN ${ }^{36}$ attempted a quantitative classification of the deposition of lipofuscin in several regions of the aged dog nervous system.

The present paper provides a systematic appraisal of the deposition of lipofuscin in the nuclei of the human brain. These data were compared with the distribution of certain oxidative enzymes (DPN-diaphorase, succinic dehydrogenase) as obtained in a detailed mapping and measurement of these enzymes in many regions of the human brain (FRIEDE and FLEMING ${ }^{16}$ ). Correlation was found between the normal gradations of enzyme activity in nerve cells and the presence of lipofuscin in these cells in the aged brain. The enzyme histochemical data were transcribed from the original paper only to the extent necessary to permit a comparison; for more detailed information the above article or the author's histochemical atlas of the cat brain stem ${ }^{15}$ should be consulted.

\section{Material and Methods \\ Identification of Lipofuscin}

Lipofuscin was identified by the following reactions (LILLIE ${ }^{22}$; SULKIN ${ }^{35,36}$ ): 1. Staining with Sudan black in both frozen and paraffin sections. The following data (No. 2-10) refer to paraffin sections only. 2. Acidfast staining with carbolfuchsin (WOLF and PAPPENHEIMER ${ }^{38}$; PAPPENHEIMER and VICTOR ${ }^{28}$ ). 3. Staining with ferric fericyanide ${ }^{22} .4$. Staining with methylgreen (POPPER, GYöRGY and GOLDBLATT ${ }^{30}$ ). 5. Weak positive reaction with Schiff's reagent (LILLIE ${ }^{21}$; SULKIN ${ }^{35,36}$ ). 6. Positive reaction with periodic acid-Schiff $4,7,8,20,21$. Weakening of the reaction after acetylation and reinforcement after deacetylation. Positive reaction after bromination. 7. Positive reaction with peracetic acid-Schiff ${ }^{21,35}$. Inconsistent weakening after acetylation; variable reaction after bromination. 8 . Positive results of the above reactions following bleaching with hydrogen peroxyde or permanganate $22,25,29.9$. Dark blue staining 1961.

* Presented, in part, at the Fourth International Congress of Neuropathology, München,

** This investigation has been supported by U. S. Public Health Grant B-3250. 
with nile blue. Removal of the nile-blue stain by short treatment with acetone (LILLIE ${ }^{23}$ ). 10. Yellow fluorescence in UV light (EINARSON ${ }^{9,10}$ ).

Other substances giving a positive reaction with periodic acid-Schiff in brain tissue were differentiated from lipofuscin as follows (SuLkis ${ }^{35}$ ): glycogen appeared in granules which were identified by the diastase test. Mucoproteins showed a diffuse distribution and no staining with the reactions $1,2,3,4,5,7,9$ and 10 .

\section{Differentiation of Lipofuscin and Melanin}

Lipofuscin and melanin were differentiated by LILLIE's methods ${ }^{23}: 1$. Staining with nile blue; lipofuscin: dark blue; melanin: dark green. 2. Short treatment with acetone after staining with nile blue; lipofuscin discolored; melanin: unchanged. 3. Bleaching with permanganate ${ }^{22,25,29}$ followed by staining with nile blue; lipofuscin: dark blue; melanin: negative 4. The other reactions for lipofuscin listed above, likewise were positive after bleaching of the melanin by permanganate.

\section{Quantitative Estimation of Lipofuscin}

The quantitative estimation of lipofuscin granules in nerve cells was difficult because of the variable cell size and the continuous accumulation of lipofuscin during lifetime. The purpose of this study was to determine the relative gradations of the extent of deposition of lipofuscin among nuclei. These gradations were classified in detail in four selected brains from patients aged 54,68,71 and 79 years; then, the classification obtained was tested by comparison with about 30 adult brains taken at random from the routine autopsy material.

A nucleus was classified "lipophil" if the majority of cells (three out of four cells or more) showed heavy deposition of lipofuscin. The classification "intermediary" implied that the intensity of deposition of lipofuscin varied greatly among cells. Nuclei were classified as "lipophob" if only a few cells (about one cell among 4, or less) contained lipofuscin or if very little lipofuscin was found in the cells. The classification "strongly lipophob" implied absence of lipofuscin in nerve cells, or such scarcity that cells containing lipofuscin had to be searched for.

It was impossible to eliminate subjective judgment in this type of classification; however, substantial subjective error was very unlikely in the categories of "lipophil" and "strongly lipophob". These two groups include about two-thirds of the nuclei listed in Table 1. As a means of control of the subjective factor, the classification of lipofuscin was finished and filed about 9 months before the enzyme study was finished. Then, data from both studies were transcribed into Table 1 and no corrections were permitted thereafter.

\section{Enzyme Histochemical Techniques}

DPN-diaphorase was demonstrated in $30 \mu$ sections fixed in formalin for a limited time under controlled conditions. Both the techniques of FARBER, STERnBerg and DunLaP ${ }^{12}$ and of Scarpelli, Hess and Pearse ${ }^{31}$ were used. Recent data comparing assays for DPN-diaphorase in tissue homogenates with measurements of the histochemical reaction in tissue sections (FrIEDe, Fleming and Kroller, in preparation) showed that the latter permits a reliable demonstration of gradations of DPN-diaphorase activity. Extensive measurements of the histochemical reaction were reported in another article ${ }^{16}$ which should be consulted for further details. The incubation period for the present material was 2 hours at $39^{\circ} \mathrm{C}$, using Nitro BT.

Succinic dehydrogenase was demonstrated in $60 \mu$ sections of unfixed tissue using Nitro BT.

The investigation was limited to DPN-diaphorase and succinic dehydrogenase, because a detailed mapping of these two enzymes, TPN-diaphorase, cytochrome oxidase and capillarization in the brain stem of the cat ${ }^{15}$ showed extremely similar patterns of distribution. Current mappings of lactic dehydrogenase likewise showed a similar pattern. The above enzymes, with a few minor exceptions, can be regarded as representative of general patterns of tissue oxidation.

Nitro BT has been used-as a routine-as an electron acceptor; testing of other tetrazolium salts (INT, TBNT, Tetrazolpurpur) gave essentially identical distribution of the reaction. Comparison of histochemical measurements (densitometry of section or spectrophotometric 
measurements of extracted formazan) with assays in tissue homogenates gave no reason to doubt the reliability of the histochemical data (FRIEDE, FLEMING and KroLLER, in preparation). Extremely low measurements in no substrate controls eliminated "nothing dehydrogenase" or adsorbtion of tetrazolium as sources of error.

\section{Lipid Solubility of Formazan}

The lipid solubility of formazan has to be considered in a study comparing the distribution of a formazan reaction and lipofuscin. The formazan from Nitro BT is practically insoluble in lipids; lipofuscin-granules always appeared as yellow, unstained granules clearly distinguishable from the dark formazan crystals. Thus, there was no indication of solubility of Nitro BT-formazan in lipofuscin.

\section{Results}

\section{Histochemical Reactions of Lipofuscin}

The 10 reactions listed under Material and Methods were positive, with minor variations, in the lipofuscin in all regions of the brain; only the reaction with Schiff's reagent (No.5) showed marked gradations among nuclei. The heavy deposits of lipofuscin in the nucl. supratrochlearis, for example, showed a weak brownish reaction with Schiff's reagent, while the lipofuscin in the adjacent trochlear nucleus stained bright red. Likewise, the lipofuscin in the cells of the inferior olivary nucleus showed a much weaker reaction with Schiff's reagent than the lipofuscin in the cells of the reticular formation. These observations suggested differences of the composition of the lipofuscin of individual nuclei.

\section{Relation of Lipofuscin to Oxidative Enzymes}

A brief description of the normal human enzyme patterns ${ }^{16}$ will help the interpretation of the following data. Oxidative enzyme activity in gray matter was found in the perikarya of nerve cells, and homogeneously distributed in the neuropil between the perikarya. Both or either could show strong or weak enzyme

Table. Scatter graph of Lipofuscin and $D P N$-diaphorase activity in the nerve cells of various nuclei.

\begin{tabular}{|c|c|c|c|c|}
\hline & \multicolumn{4}{|c|}{ Description of DPN-diaphorare activity in nerve cells } \\
\hline & $\begin{array}{l}\text { "No cells distin- } \\
\text { guishable" by } \\
\text { enzymatic activity }\end{array}$ & $\begin{array}{l}\text { "Few cells distin- } \\
\text { guishable" or } \\
\text { "weak reaction } \\
\text { in cells" }\end{array}$ & $\begin{array}{l}\text { "Nedium reaction } \\
\text { in cells" or "mixed } \\
\text { cell population" }\end{array}$ & $\begin{array}{l}\text { "Strong or very } \\
\text { strong reaction" }\end{array}$ \\
\hline Strongly lipophob & $\begin{array}{l}4,11,19,24,30, \\
36,41,96,56, \\
57,58\end{array}$ & 31,38 & & 45 \\
\hline Lipophob & $7,21,26,49,63$ & $\begin{array}{l}1,2,9,13,23 \\
28,35,37,42 \\
62,62\end{array}$ & 39 & \\
\hline Intermediary & & 10 & $8,33,44,55,64$ & $22,27,48$ \\
\hline Lipophob & & & & $\begin{array}{l}2,5,6,12,14, \\
15,16,17,18, \\
20,25,29,32, \\
34,40,43,47, \\
50,51,53,54, \\
59,60,61,65, \\
66\end{array}$ \\
\hline
\end{tabular}


activity. The resulting complex patterns of enzyme distribution were consistent and characteristic for any given nucleus. Elaborate descriptions of these normal chemoarchitectonic patterns are available ${ }^{13-16}$. The Table provides a scatter graph comparing the extent of deposition of lipofuscin in nerve cells with the enzyme activity in the perikarya of the nerve cells.

\section{Names of nuclei listed in the Table:}

1. Area postrema; 2. Nucl. n. hypoglossi; 3. Nucl. intercalatus; 4. Nucl. tractus solitarii; 5. Nucl. ambiguus; 6. Nucl. olivaris inferior; 7. Nucl. tractus spinalis trigemini; small cells; 8. Same; large cells; 9. Nucl. vestibularis medialis; 10 . Nucl. vestibularis spinalis; 11 . Nucl. paramedianus dorsalis oralis; 12 . Nucl. n. facialis; 13 . Substantia reticularis; pars lateralis; 14. Nucl. reticularis lateralis; 15 . Nucl. reticularis paramedianus; 16 . Nucl. reticularis gigantocellularis; 17 . Nucl. vestibularis lateralis; 18 . Nucl. n. abducentis; 19 . Griseum centrale (pontis); 20. Nucl. nervi trigemini mesencephalicus; 21. Nucl. parabrachialis; 22. Nucl. lemnisci lateralis ventr.; 23. Nucl. lemnisci lateralis dors.; 24. Nucl. sagulum; 25. Nucl. nervi trigemini motorius; 26. Nucl. nervi trigemini sensibilis principalis; 27. Nucl. reticularis pontis pars medialis; 28. Same; pars lateralis; 29. Nucl. papilioformis (Nuc. reticularis tegmenti Bechterew); 30. Colliculus inferior; 31. Griseum centrale mesencephali; 32. Nucl. supratrochlearis; 33. Nucl. cuneiformis, subcuneiformis; 34. Nucl. oculomotorius; 35. Nucl. Edinger Westphal; 36. Nucl. interpeduncularis; 37. Nucl. paranigralis; 38. Substantia nigra, subnucl. compactus; 39. Substantia nigra, subnucl. reticularis; 40. Nucl. ruber (pars magnocellularis); 41. Colliculus superior; superficial gray layer; 42. Same; intermed. gray layer; 43. Same; deep gray layer; 44. Nucl. Darkschewitsch; 45. Purkinje cells (cerebellum); 46. Granular cells (cerebellum); 47. Nucl. dentatus; 48. Nucl. fastigii; 49. Putamen and nucl. caudatus; small cells; 50. Same; large cells; 51. Pallidum; 52. Amygdaloid nuclear group; 53. Nucl. mammillaris; 54. Nucl. subthalamicus; 55. Zona incerta; 56. Hypothalamus, medial portion; 57. Nucl. paraventricularis; 58. Nucl. supraopticus; 59. Nucl. reticularis thalami; 60 . Nucl. lateralis thalami; 61. Nucl. ventralis lateralis thalami; 62 . Nucl. ventralis medialis thalami; 63. Midline nuclear group (thalamus); 64. Nucl. posterior thalami; 65. Pulvinar; 66. Nucl. geniculatus lateralis.

The following nuclei were not included in the scatter graph because of variance of the content of lipofuscin:

67. Nucl. cuneatus lateralis; 68 . Nucl. prepositus hypoglossi; 69. Substantia reticularis; pars medialis; 70. Griseum pontis; 71. Nucl. olivaris superior; 72. Nucl. vestibularis superior; 73. Nucl. centralis superior; 74. Claustrum; 75. Hypothalamus, lateral portion; 76. Nucl. anterius thalami; 77. Nucl. dorsomedialis thalami; 78. Nucl. geniculatus medialis.

Lipophil cells were always found in nuclei in which the perikarya of the nerve cells exhibited strong enzyme activity (Table). Lipophob cells were found in nuclei in which the perikarya had weak or no enzyme activity -thus being not distinguishable from the neuropil. In some of these nuclei, perikarya were even outlined from the neuropil by the lack of a reaction.

These relationships were particularly evident where nuclei with strikingly different enzyme patterns bordered each other (Fig. 1-4). The cell populations of such nuclei were sharply separated by a gradient of the deposition of lipofuscin. The cells of the nucl. supratrochlearis (No.32), for example, were delineated from the adjacent central gray (No.31) by strong deposition of lipofuscin. These cells were characterized by strong enzyme activity in the perikarya, while the cells of the central gray showed very little, if any, in the perikarya.

Some nuclei with a mixed cell population showed different deposition of lipofuscin in the various cell types. For example, the small cells in the putamen (No.49) were lipophob and the large cells (No.50), lipophil. This pattern reflected. the enzyme distribution in this nucleus, where only large perikarya were distin- 
guishable by enzyme activity while the small perikarya were not discernible from the neuropil. Other examples were the nucl. tractus spinalis trigemini $($ No. 7,8$)$, the colliculus superior (No.41,42,43), and the pigmented nuclei which are described below.

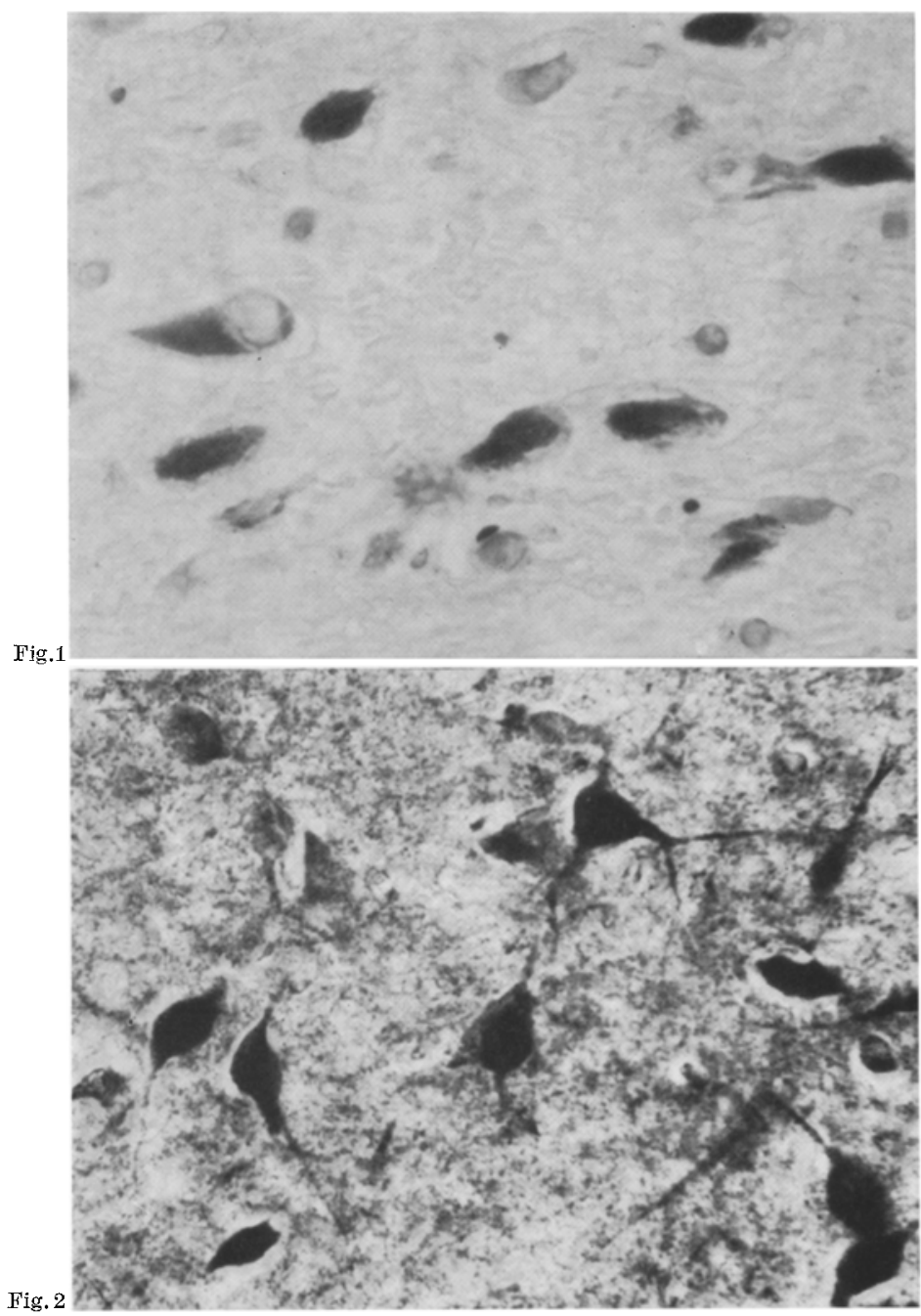

Figs. 1 and 2. Nucleus supratrochlearis. Fig. 1 shows heavy deposition of lipofuscin (PAS-stain). Fig. 2 shows strong activity of DPN-diaphorase in the cells. $300 \times$

There was a definite relation of the extent of deposition of lipofuscin to enzyme activity in the perikarya of most regions; however, the ependyma and Purkinje cells (No.45) clearly represented exceptions (see below).

The relative intensity of enzyme activity in the neuropil was not relevant to the presence of lipofuscin in perikarya as shown, for example, by comparing the colliculus inferior (No.30; no activity in perikarya but very strong reaction in neuropil) with the griseum centrale (No.31; no activity in the perikarya and very 
weak activity in the neuropil). Accordingly, the total enzyme activity in both perikarya and neuropil of a nucleus was not a parameter for the presence of lipofuscin in nerve cells (for measurements, consult 16).

Data concerning the presence of lipofuscin in neuropil were not included in the Table because of the difficulties to quantitatively estimate lipofuscin in neuro-

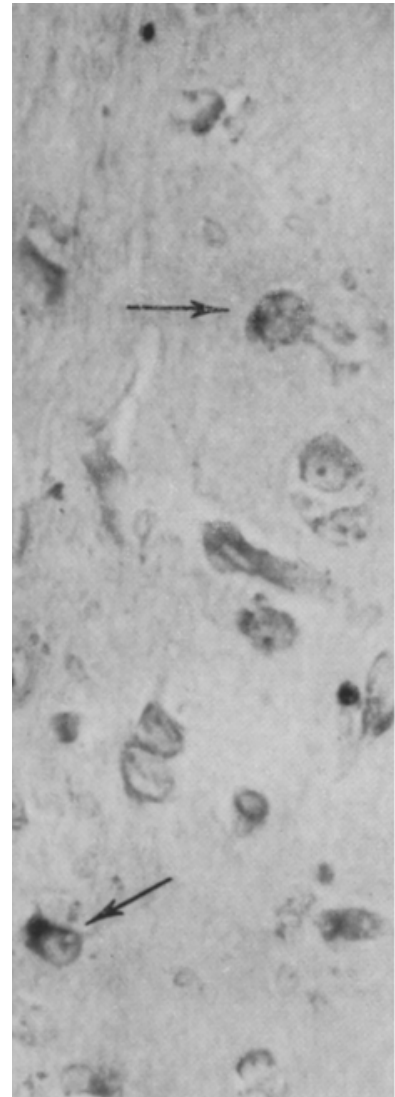

Fig.3

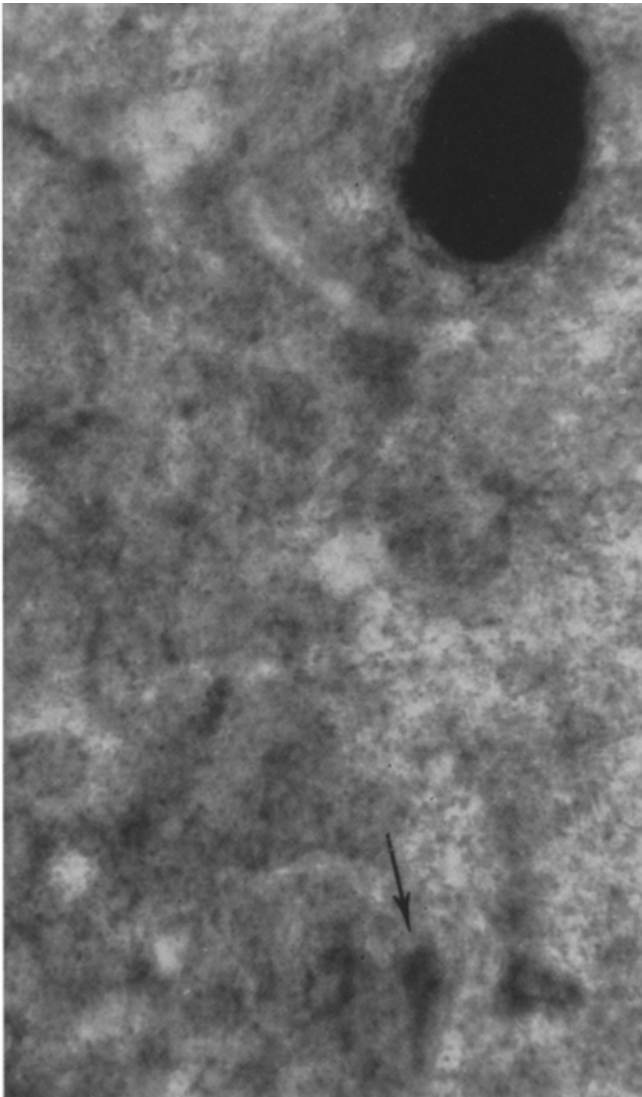

Fig. 4

Figs. 3 and 4. Griseum centrale. Fig. 3 shows no lipofuscin in nerve eells, save a few (arrows); the cells are demonstrated by a weak counterstaining with chromalum-gallocyanin. Fig. 4 shows the distribution of succinic denydrogenase in the homologous region. Nerve cells are not distinguishable from the diffuse activity in the neuropil, save a few (arrow). The oval dark area represents one cell of the nucl. tractus mesencephaliei n. trigemini, showing very strong activity. $300 \times$

pil. Regions with strong or very strong enzyme activity in the neuropil showed a diffuse distribution of lipofuscin granules, partly incorporated in the perikarya of glia cells, or in peri-vascular deposits. The molecular layers of the cerebral cortex, the upper colliculus, and the cerebellar cortex showed lipofuscin incorporated in glial cells, mostly astrocyteś, with a gradient toward the pia mater where lipofuscin was found in macrophages and attached to larger blood vessels. The amount of lipofuscin in the neuropil of nuclei did not show the clear-cut proportions to the gradations of enzyme activity which characterized the perikarya. 
These data suggested that lipofuscin was formed in the neuropil, however, did not remain there, but was being incorporated in glia cells and removed toward the vessels or the pia. This would explain the poor correlation of the amount of lipofuscin in neuropil and enzyme activity. In conclusion, it was assumed that two factors seemed to determine the amount of lipofuscin visible in the tissue: 1. The formation of lipofuscin, being proportional to the intensity of the local

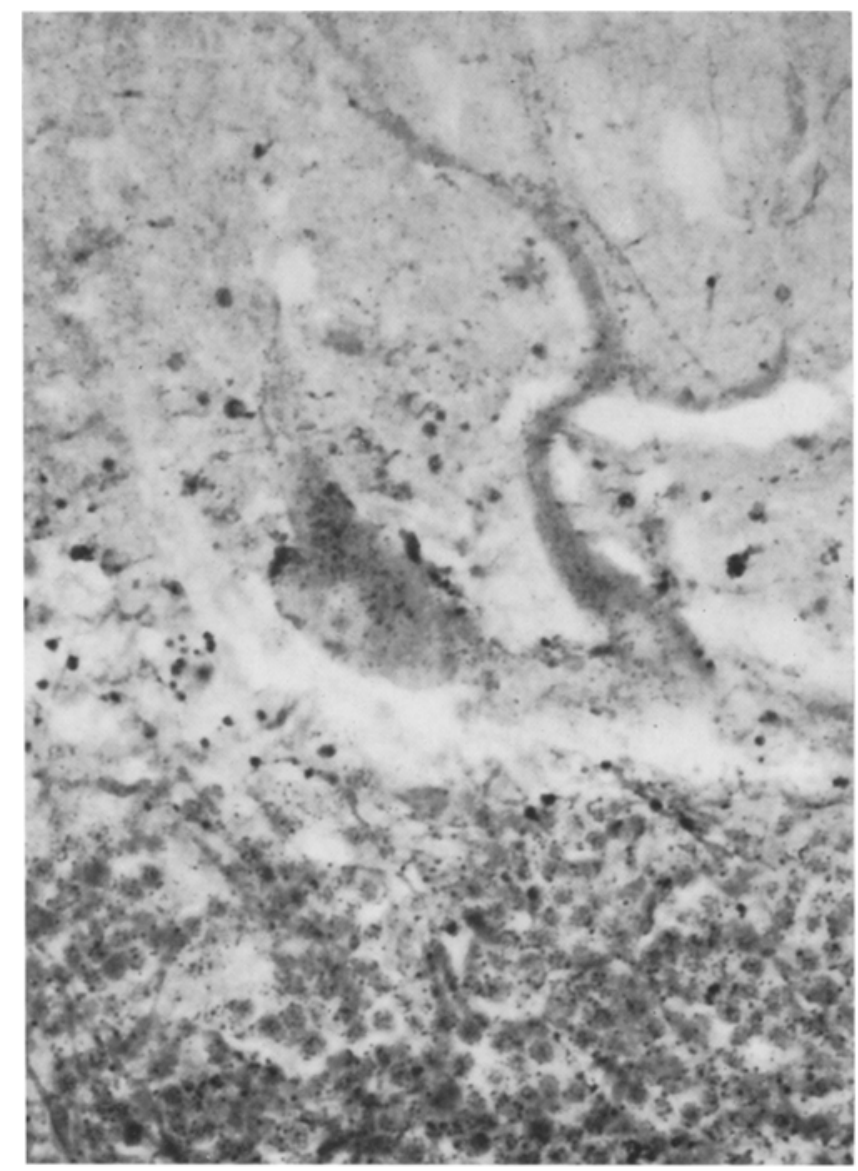

Fig. 5. Absence of lipofusein in a Purkinje cell and heavy deposition of granules in the surrounding glia cells. Sudan black. $560 \times$

oxidative metabolism (gradations of enzymatic activity). 2. The removal of lipofuscin which appeared to be difficult from the perikarya but less difficult from the neuropil.

This concept was supported by findings in the two exceptional regions mentioned above: The cerebellar Purkinje cells (No.45) were strongly lipophob, while their perikarya showed very strong enzyme activity; however, the surrounding glial cells were exceptionally loaded with lipofuscin granules. This relationship has been described by other authors ${ }^{26,32,33}$ and was interpreted as indicating removal of lipofuscin from the Purkinje cells (Fig. 5). The Purkinje cells, therefore, 
may have a specific mechanism for the removal of lipofuscin from their perikarya, which was absent or less developed, in other nerve cells. The exceptional loading of the surrounding glia cells with lipofuscin, observed only in the Purkinje layer, indicated that this region was exceptional only as to the distribution, but not as to the total presence of lipofuscin, the latter being proportional to enzyme activity. The ependymal cells which were characterized by strong enzyme activity but little lipofuscin, likewise showed a loading of the adjacent subependymal glia cells with granules of lipofuscin.

\section{White Matter}

Lipofuscin was found in white matter in or about glia cells and in perivascular deposits; it was absent in myelin sheaths and in axons. White matter showed strikingly less lipofuscin than gray matter and this gradient was proportional to the weak oxidative enzyme activity in white matter ${ }^{15}$.

\section{Pigmented nuclei}

Lipofuscin and melanin in pigmented cells were distinguished by the reactions described above ${ }^{23}$. Since the pattern of DPN-diaphorase and succinic dehydrogenase differed somewhat in the pigmented nuclei, the following data apply to succinic dehydrogenase only. Two cell types were distinguished in the nucl. coeruleus and in the substantia nigra. A small fraction of the cell population, mostly the smaller cells, lacked melanin and were lipophil. These cells were characterized by strong activity of succinic dehydrogenase. The larger portion of the cell population showed a heavy deposition of melanin granules covering all other structures in the cytoplasm; after bleaching of the melanin, a few lipofuscingranules became visible ${ }^{2}$ but much less than in the non-pigmented cells. These pigmented cells showed little succinic dehydrogenase activity.

The inverse relationship of melanin to lipofuscin and succinic dehydrogenase activity was also found in other pigmented nuclei ${ }^{27}$, such as the pigmented cells in the nucl. dorsalis vagi, the area postrema and others. One might argue that the weak enzyme activity and the deposition of lipofuscin in pigmented cells resulted from a mechanical displacement of cytoplasm by the pigment granules. However, these nuclei showed little enzyme activity in animals in which they were not pigmented ${ }^{13-15}$.

The melanophores in the leptomeninges showed a heavy deposition of melanin and absence of both lipofuscin and oxidative enzyme activity.

\section{Intracellular relationship of Lipofuscin and Oxidative Enzymes}

Lipofuscin granules never showed any activity of oxidative enzymes. The yellow granules of lipofuscin were readily distinguished from the dark blue formazan crystals in the histochemical preparations; there was also no indication of solubility of formazan in lipofuscin. The activity of DPN-diaphorase or succinic dehydrogenase in the cytoplasm did not change near the lipofuscin; this seemed to support electron microscopic data which disclaim the contention that lipofuscin originates from degenerated mitochondria ${ }^{1}$. A very heavy deposition of lipofuscin caused a mechanical displacement of the cytoplasm and thus a decrease 
of the total enzyme activity of the perikaryon. In some nuclei, such as the inferior olivary nucleus, the mechanical displacement was so extensive that the perikarya were almost depleted of cytoplasm containing enzyme activity. This mechanical displacement of cytoplasm and its enzyme activity might likely interfere with the cell's metabolism resulting in pigment-degeneration ${ }^{9,10}$; this is commonly observed in the inferior olivary nucleus, in which the cell population decreases markedly with aging ${ }^{27}$.

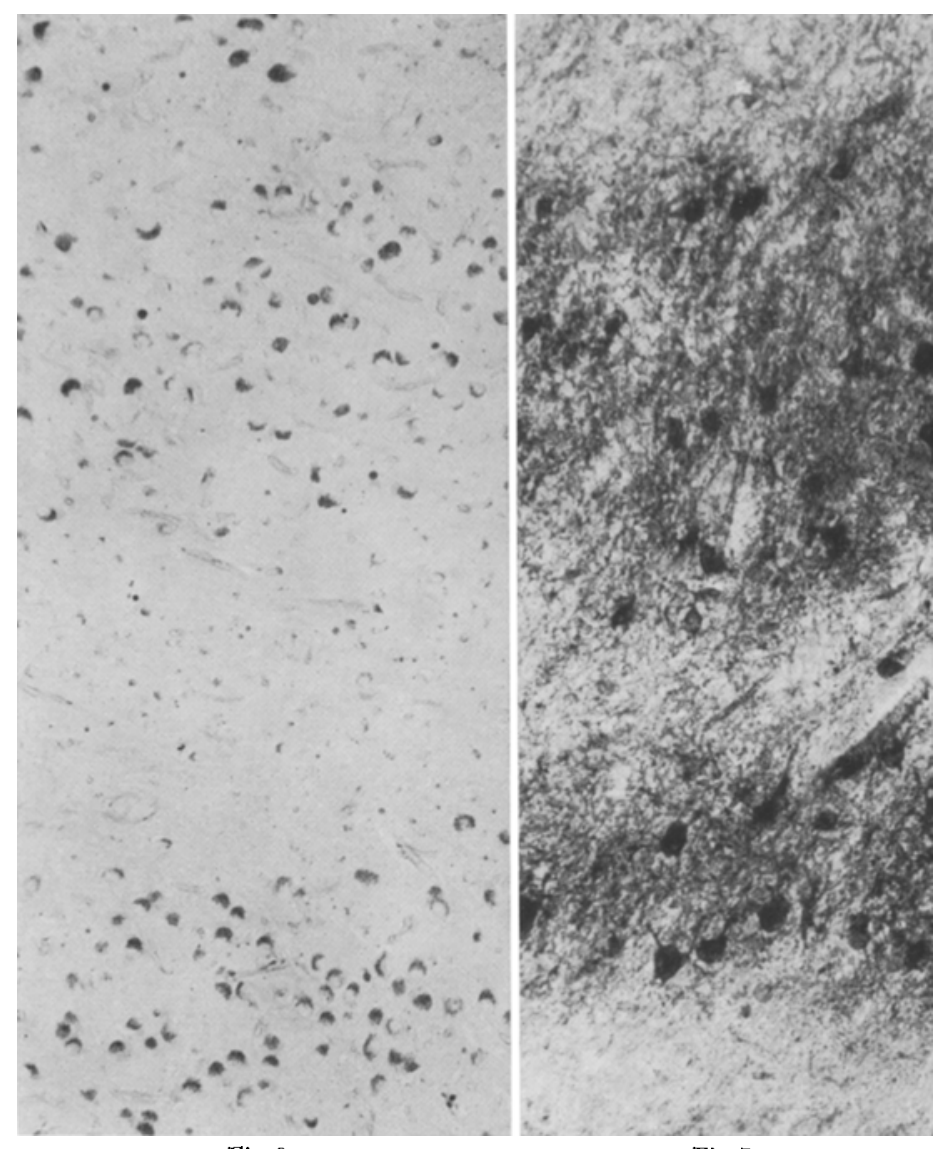

Fig. 6

Fig. 7

Fig. 6. Decreased amount of lipofuscin in alternate layers of the lateral geniculate body. PA S-reaction; since the section is not counterstained, the (atrophic) nerve cells without lipofuscin are barely visible. $80 \times$

Fig. 7. Decrease of DPN-diaphorase activity in alternate layers following removal of one eye. The individual layers are thinner than in Fig. 6, because the section demonstrates the peripheral portion of the nucleus. $120 \times$

\section{Changes in Lipofuscin and Enzyme Activity as a Result of Changes of Functional Activity}

The above data evidenced a relation between the normal gradations of oxidative enzyme activity in perikarya and the deposition of lipofuscin in the aged human brain. The question arose as to whether these gradations were inherent and permanent properties of the individual nuclei, or whether they would change with functional activity. This question was answered by the findings in the corpus 
geniculatum laterale in two patients who had lost one eye: A woman of 71 years, who had lost one eye (enucleation) at the age of 16 ; a man of 72 years whose left eye had been blind "for years" (atrophia bulbi) following a "traumatic incident". The latter brain was obtained soon after death and serial enzyme histochemical sections for DPN-diaphorase were made.

Since the optic fibers from the right and left eye terminate in alternate layers of the corpus geniculatum laterale, one set of layers served as a control for the other. Change of the layers were readily recognized since other factors, such as thickness of sections, variance of incubation medium or incubation time were eliminated. Normally, adjacent layers showed equal enzyme activity and equal deposition of lipofuscin. In the above cases, the deposition of lipofuscin in the atrophic nerve cells was strikingly reduced, producing a conspicuous pattern of alternate lipophil and lipophob layers (Fig.6). DPN-diaphorase activity likewise was decreased in both perikarya and neuropil of alternate layers (Fig. 7); this pathological pattern was readily seen even with the naked eye.

These observations suggested that functional activity, oxidative enzymatic activity, and deposition of lipofuscin were related. It seemed of particular significance that the atrophy by inactivity was followed by decreased deposition of lipofuscin.

\section{Discussion}

Table 1 showed that nerve cells with strong activity of oxidative enzymes in their perikarya contained more lipofuscin at age than nerve cells with little enzyme activity in their perikarya. The normal gradations of enzyme activity among cells thus established a parameter for the later deposition of lipofuscin. The correlation of deposition of lipofuscin and enzyme activity was less evident in neuropil and Purkinje cells. These structures showed histological indication of incorporation and removal of lipofuscin by glial cells; in the Purkinje cells this process has been confused with neurosecretion ${ }^{32}$. It was theorized, therefore, that lipofuscin was being more readily removed from neuropil and Purkinje cells than from other nerve cells.

The formation of lipofuscin in regions with strong enzymatic activity was in accordance with the observation that other organs characterized by heavy deposition of lipofuscin (heart, liver) likewise contain very strong oxidative enzyme activity.

A correlation of enzymatic activity, functional activity, and deposition of lipofuscin was suggested by the decrease of both enzyme activity and lipofuscin in alternate layers of the lateral geniculate nucleus following removal of one eye. The presence of the "wear and tear" pigment, therefore, depended on the intensity of the "metabolic wear and tear" which was indicated by the gradations of the oxidative enzyme activity.

These data did not imply a direct formation of lipofuscin from or by the oxidative enzymes; there was no indication whatsoever of activity of oxidative enzymes in lipofuscin or changes activity in the vicinity of lipofuscin. This was in contrast to the histochemical demonstration of other enzymes, such as esterase ${ }^{17,18,29}$ in lipofuscin. While such data imply more specific relations between these enzymes and lipofuscin, our data imply only that the more active and 
oxidative metabolism there is in a given region, the greater is the likelihood of accumulating lipofuscin.

Lipofuscin is chemically akin, if not identical, with the ceroid pigment ${ }^{21,24}$ found in vitamin $\mathrm{E}$ deficiency ${ }^{5,6,9-11,30,38}$. The histochemical properties of both lipofuscin and the pigment of vitamin $\mathrm{E}$ deficiency are similar ${ }^{28}$. PEARSE ${ }^{29}$ concludes that ceroid represents a typical lipofuscin in an early state of oxidation.

CASSELMAN and BRUCE ${ }^{3}$ synthetized a substance with the histochemical properties of ceroid; their data suggested that the auto-oxidation of unsaturated fatty acids to ceroid is favored if these acids accumulate in the tissue to an extent that a relative lack of biological antioxidants results. This theory may explain the relationship of oxidative enzyme avticity and lipofuscin found in our study, since the effects of a lack of antioxidants will be aggravated with the rate of the oxidative metabolism.

It was considered an important result of this study to demonstrate that the chemical architecture of the normal brain determined the predilection of certain senile alterations; this seemed to open an avenue for the understanding of predilection of neuropathological changes. The concept of pathoklisis (VoGT ${ }^{37}$ ) - which postulated "physico-chemical" differences among nuclei as the cause of selective damage-gains more and more support by studies of chemoarchitecture.

\section{Summary}

The extent of deposition of lipofuscin in 66 nuclei of the aged human brain was classified systematically and the data were compared with the distribution of certain axidative enzymes (succinic dehydrogenase, DPN-diaphorase). Nerve cells characterized by strong activity of oxidative enzymes in their perikarya contained more lipofuscin in aged brains than nerve cells characterized by little enzyme activity. The normal gradations of enzymatic (and probably metabolic) activity among cells thus predetermined - to a certain extent-the later deposition of lipofuscin. The lipofuscin in the neuropil (dendrite branchings) did not show the clear-cut relation to enzyme activity which characterized the perikarya; there was some indication of removal of lipofuscin from neuropil.

A correlation between functional activity, oxidative enzymatic activity and deposition of lipofuscin was suggested by the findings in two cases in which, following the removal of one eye, alternate layers of the lateral geniculate nucleus showed a marked decrease of DPN-diaphorase activity and decreased presence of lipofuscin. The presence of "wear and tear" pigment, therefore, appeared related to the functional "wear and tear" of a given region which is reflected by the intensity of oxidative metabolism. Cytological studies, on the other hand, did not imply a more specific association of lipofuscin with oxidative enzyme activity.

\section{Zusammenfassung}

Das Ausmaß der Lipofuscinablagerung in 66 Kernen des gealterten menschlichen Gehirns wurde systematisch klassifiziert und die Ergebnisse wurden mit der Verteilung gewisser oxydativer Enzyme (Succinodehydrogenase, DPN-diaphorase) verglichen. Nervenzellen mit starker Aktivität der oxydativen Enzyme in den Perikarya wiesen mit zunehmendem Alter größere Lipofuscinansammlungen auf als Nervenzellen mit geringer Aktivität in den Perikarya. Daraus ist zu sehen, 
daß die Menge der späteren Lipofuscinablagerungen in gewissem Maße durch die normalen Unterschiede zwischen der enzymatischen (und vielleicht metabolischen) Tätigkeit der einzelnen Zellen bestimmt wird. Das im Neuropil (in den Dendritenverzweigungen) gebildete Lipofuscin scheint aus dem Gewebe abtransportiert zu werden; es zeigt daher nicht das deutlich sichtbare Verhältnis zur Enzymaktivität, wie es für die Perikarya charakteristisch ist.

Die Annahme einer Verbindung zwischen funktioneller Aktivität, der Aktivität von oxydativen Enzymen und späteren Lipofuscinablagerungen werden durch Befunde bei 2 Fällen nahegelegt, bei denen nach Entfernung eines Auges die alternierenden Schichten des Nucleus geniculatus lateralis eine beträchtlich verminderte DPN-diaphorase-Tätigkeit und verminderte Lipofuscinablagerung zeigten. Die Bildung von ,Abnützungs"s-Pigment scheint daher in Abhängigkeit von der funktionellen ,Abnützung" einer bestimmten Region zu stehen, wobei sich diese Abnützung in der Intensität des oxydativen Stoffwechsels widerspiegelt. Andererseits weisen cytologische Studien auf keine nähere Beziehung des Lipofuscins zur oxydativen Enzymaktivität hin.

\section{Bibliography}

1 Bondareff, W.: Genesis of intracellular pigment in the spinal ganglia, of senile rats. J. Geront. 12, 364-369 (1957).

${ }^{2}$ Calligaris, C.: Beiträge zum Studium der Zellen des Locus coeruleus und der Substantia nigra. Mschr. Psychiat. Neurol. 24, 339-353 (1908).

${ }^{3}$ Gasselman, W., and W. BRUCE: The in vitro preparation and histochemical properties of substances resembling ceroid. J. exp. Med. 94, 549-562 (1951).

4 Crara, M.: Untersuchungen über die tropfigen Einschlüsse in menschlichen Nervenzellen. Psychiat. Neurol. med. Psychol. (Ipz.) 5, 108-120 (1953).

${ }^{5}$ D'ANGelo, C., M. Issidorides and W. M. SHANkita: A comparative study of the staining reactions of granules in the human neuron. J. comp. Neurol. 106, 487-505 (1957).

$6,-,-$, A comparative study of the staining reactions of granules in the human brain. Anat. Rec. 124, 397-398 (1956).

7 Dixon, K. C., and B. M. HeRBertson: Clusters of granules in humanneurons. J. Path. Bakt. 62, 335-339 (1950).

8 -, -: A cytoplasmic constituent of the brain. J. Physiol. (Lond.) 111, 244-247 (1950).

${ }^{9}$ Einarison, L., and A. Ringsted: Effect of chronic vitamin E deficiency on the nervous system and the skeletal musculature in adult rats. Kovenhagen: Levin and Munksgaard 1938.

10 - Criticizing review of the concept of the neuromuscular lesions in experimental vitamin $\mathrm{E}$ deficiency preferably in adult rats. Acta psychiat. (Kbh.) Suppl. 78, 1-76 (1952).

11 Elleptiann, H., H. KaUnitz and C. A. StaneTZ: Histochemistry of uterine pigment in vitamin E deficient rats. Ann. N.Y. Acad. Sci. 52, 72-79 (1944).

${ }^{12}$ Farber, E., W. H. Sternberg and C. E. Duntap: Histochemical localization of specific oxydative enzymes. I. Tetrazolium stains for diphosphopyridine nucleotide diaphorase and triphosphopyridine nucleotide diaphorase. J. Histochem. Cytochem. 4, 254-284 (1956).

13 FrIEDE, R. L.: Histochemical investigations on succinic dehydrogenase in the central nervous system. II. Atlas of the medulla oblongata of the guinea pig. J. Neurochem. 4, 111 (1959).

11 - Histochemical investigations on succinic dehydrogenase in the central nervous system. III. Atlas of the midbrain of the guinea pig. J. Neurochem. 4, 290-303 (1959).

15 -, A histochemical atlas of tissue oxydation in the brain stem of the cat. Basel, New York: Karger 1961.

16 -, and L. M. Fleming: A mapping of oxidative enzymes in the human brain. J. Neurochem. 9, 179-198 (1962). 
17 GEDiGK, P., and E. BontKe: Über den Nachweis von hydrolytischen Enzymen in Lipopigmenten. Z. Zellforsch. 44, 495-518 (1956).

${ }^{18}$ Gouori, G.: Histochemistry of human esterases. J. Histochem. Cytochem. 3, 479-484 (1958).

19 Jаков, A.: Anotomie und Histologie des Großhirns. Wien: Deuticke 1927.

${ }^{20}$ LILLIE, R. D.: Further exploration of the $\mathrm{HIO}_{4}$-Schiff reaction with remarks on its significance. Anat. Rec. 108, 239-253 (1950).

21 - Ethylenic reaction of ceroid with performic acid and Schiff reagent. Stain Technol. 27, $37-45$ (1952).

22 -, Histopathological technique and practical histochemistry. Philadelphia: Blakiston 1954.

${ }^{23}$-, A nile blue staining technique for the differentiation of melanin and lipofuscin. Stain Technol. 31, 151-154 (1956).

${ }^{24}-$, F. S. DAFT and W. W. SEBRELL: Cirrhosis of the liver in rats on a deficient diet and the effect of alcohol. Publ. Hlth Rep. (Wash.) 56, 1255-1258 (1941).

${ }^{25}$ LISON, L. : Histochimie animal. Paris: Gauthier Villars 1936.

${ }^{26}$ OBersterner, H.: Anleitung zum Studium des Baus der nervösen Zentralorgane. Wien: Deuticke 1912.

27 OLSzEwski, J., and D. Baxter: Cytoarchitecture of the human brain stem. Montreal, Philadelphia: Lippincott 1959.

${ }^{28}$ Pappenheimer, A. M., and J. Victor: "Ceroid" pigment in human tissue. Amer. J. Path. 22, $395-413$ (1946).

${ }^{29}$ Pearse, A. G. E.: Histochemistry, theoretical and applied. Boston: Little, Brown 1961.

30 Popper, H., G. György and H. GoldBLATT: Fluorescent material (ceroid) in experimental nutrition cirrhosis. Arch. Path. 37, 161-168 (1944).

31 Scarpeliti, D. G., R. Hess and A. G. Prarse: The cytochemical localization of oxidative enzymes. I. Diphosphopyridine nucleotide diaphorase and triphosphopyridine nucleotide diaphorase. J. biophys. biochem. Cytol. 4, 747-752 (1958).

${ }^{32}$ Shanklin, W. M., M. Issidorides and T. K. NAssar: Neurosecretion in the human brain. J. comp. Neurol. 107, 315-337 (1957).

${ }^{33}$ SPIEget, E. A., and J. Sommer: Úber die histologischen Veränderungen des Kleinhirnes im normalen Senium. Arb. neurol. Inst. Univ. Wien 22, 80-105 (1917).

${ }^{34}$ Spielmeyer, W.: Histopathologie des Nervensystems. Berlin: Springer 1922.

${ }^{35}$ SULKIN, N. M.: Histochemical studies of the pigments in human autonomic ganglion cells. J. Geront. 8, 435-445 (1953).

36 - The properties and the distribution of PAS positive substances in the nervous system of the senile dog. J. Geront. 10, 135-144 (1955).

${ }^{37}$ Vogt, O.: Der Begriff der Pathoklise. J. Psychol. Neurol. (Lpz.) 32, 245-255 (1925).

${ }^{38}$ Wolf, A., and A. M. Pappentremmer: Occurrence and distribution of acid fast pigment in the central nervous system. J. Neuropath. exp. Neurol. 4, 402-406 (1945).

ReinhaRd L. Friede, M. D., Mental Health Research Institute and Laboratory of Neuropathology, University of Michigan, Ann Arbor, Michigan/USA 